\title{
The fourth transformation in Mexico, a baseline to its evaluation in health issues
}

\begin{abstract}
In Mexico, the new government tries to achieve a fourth transformation, the presidential vision has focused on eliminating privileges, having austerity and combating corruption as a means to achieve improvements in the living conditions of the country, the Comprehensive Health Plan has set the goal that in just two years Mexico has a new public health system capable of providing free care and medication to the entire population. However, the index of social backwardness and the high rates of maternal and infant mortality that in some states are very high, represent a great challenge to this fourth transformation. The statistical exercise showed significance for the indexes of social backwardness and Maternal and Infant Mortality, a Beta value of $-.719, \mathrm{p}<.001$ and $\mathrm{R}^{2}=0.3896$, which would imply that up to $38.9 \%$ of the maternal and infant mortalities would be explained by the social backwardness index. If the fourth transformation is fruitful, the backwardness index will be reduced, especially in the states where this index has the highest figures, so it would have a favorable impact on the Maternal and Infant Mortality indexes.
\end{abstract}

Keywords: public policy, health services, maternal mortality, infant mortality, mexico, fourth transformation
Volume 6 Issue 2 - 2019

\author{
Rey Arturo Salcedo-Álvarez,' Blanca \\ Consuelo González-Caamaño,' Sara Huerta- \\ González, ${ }^{2}$ Andrea del Prado-Vázquez,' \\ María de Lourdes Alemán-Escobar, ${ }^{3}$ y Rosa \\ Amarilis Zárate-Grajales' \\ 'Escuela Nacional de Enfermería y Obstetricia, Universidad \\ Nacional Autónoma de México, México \\ ${ }^{2}$ Universidad Veracruzana, México \\ ${ }^{3}$ Secretaría de Salud, Instituto Nacional de Salud Pública, México
}

Correspondence: Rey Arturo Salcedo Álvarez, Escuela Nacional de Enfermería y Obstetricia, Universidad Nacional Autónoma de México, Camino viejo a Xochimilco S/N y Viaducto Tlalpan Col. San Lorenzo Huipulco, C. P. I4370, Mexico, Tel 0I525655I342,Email rasalced@hotmail.com

Received: February 27, 2019 | Published: March 27, 2019

\section{Background}

\section{The fourth transformation}

Since December 1st 2018, the new government in Mexico has set itself the goal of achieving a historic transformation, called the "Fourth Transformation"; the three previous transformations were: a) The Mexican Independence of the Spanish crown (1810 to 1821); b) the Reformation movement, where the separation of church and state was emphasized (1858 to 1861); and c) the Mexican Revolution, armed conflict that ended with the promulgation of the Political Constitution that currently governs the country (1910 and 1917). ${ }^{1-4}$ In general terms the "Fourth Transformation" refers to the presidential vision of his future government that includes eliminating the privileges of the high bureaucracy, implementing an austerity plan and fighting corruption to achieve a deep change to improve living conditions of the country, being the health of Mexicans one of the main axes of this transformation.

\section{Legislation and determinants in health}

Lawfully, health is guaranteed in the Mexican Political Constitution $^{5}$ and in the General Health Law; ${ }^{6}$ however, there are a series of social determinants that influence welfare, being the social characteristics in which life develops, the conditions in which people live and work, the interactions of lifestyles, the environment, human biology and the organization of health services some of the elements that determine the health levels of the population; ${ }^{7}$ but so are all those aspects inherent to the conditions in which people are born, grow, live, work and grow old, as well as the position they occupy in the social hierarchy; It also interacts with the governance that integrates the economic, political and administrative processes through which authority is exercised, considering social participation and accountability; thus the macroeconomic policies underlying the labor market and public policies, the cultural and social values that condition social welfare and the health of the population as a whole. Therefore, from a Comprehensive Health Plan, it is described in detail what will be the public policy on health. ${ }^{8-11}$

\section{The comprehensive health plan}

The Comprehensive Health Plan has not yet been published; but official sources have given in advance some general aspects of what it will be, through this plan it is intended that in two years Mexico has a new public health system capable of providing free care and medication to the entire population. When announcing the Comprehensive Health Plan, it was explained that this strategy includes federalizing health services; in a first stage, 25 billion pesos will be invested in the eight federal entities of the country that present the greatest social backwardness and serious public health problems (Figure 1). The new plan aims to guarantee the Ministry of Health, the Institute of Social Security and Services of State Workers, as well as the Mexican Social Security Institute the right to first level care, hospital care and emergency medical services, as well as patient transfers, regardless of whether the persons are entitled or not; and offer conditions of equality under a policy of zero corruption. ${ }^{12,13}$

\section{Main challenges for the transformation}

The best way to verify the result of a public policy is that over time tangible changes can be observed in the different scenarios, thus the Social Backwardness Index, which is a weighted measure that summarizes four indicators of social scarcity (education, health, basic services and spaces in the home) in a single index, has the purpose of ordering the observation units according to their social needs. This index allows the generation of information for decision making in social policy matters, it is especially helpful to analyze the inequality of social coverage. The Social Backwardness Index is calculated with a series of variables associated with the dimensions of education, access to health services, basic services in housing, housing quality and household assets. These variables consist of the proportion of: illiterate population of 15 years or more, population from 6 to 14 years who does not attend school, population of 15 years and more with incomplete basic education, population without entitlement to health services, housing with ground floor, dwellings that do not have toilets, dwellings that do not have piped water from the public network, dwellings that do not have drainage, dwellings 
that do not have electricity, dwellings that do not have a washing machine, and dwellings that do not have a refrigerator. ${ }^{14-16}$ To reduce the Index of Social Backwardness is the first challenge of the Fourth Transformation.

\section{Global index of maternal and infant mortality}

For the construction of the Global Index of Maternal and Infant Mortality, the two most important causes of death, social interest and vulnerability were selected; these two causes are paradoxically also preventable, treatable and curable since advances in health sciences have technology enough to prevent these early deaths. In Mexico, more than 1,000 women die each year from complications of pregnancy, childbirth and puerperium. Most of these complications occur during pregnancy and are preventable or treatable; others may be present before pregnancy, but are aggravated with pregnancy, especially by not receiving treatment as part of Prenatal care, many of these are pregnancies at non-ideal ages. The main complications, which cause $75 \%$ of maternal deaths, are: hemorrhages, infections, preeclampsia and eclampsia, complications in childbirth and abortions. ${ }^{17}$

Although, infant mortality has decreased in recent years, ${ }^{18}$ it is a reality that most infant deaths are related to conditions originating in the perinatal period and congenital malformations, deformities and chromosomal anomalies, which due to their complexity are difficult to treat or even do not have a treatment; however, a minor proportion of these deaths of approximately $15 \%$ is related to well-defined causes that do have a diagnosis, treatment or prevention, such as infections, accidents, intentional attacks and malnutrition. ${ }^{19}$

The reason why people die reflects the way they live, that is why the most sensitive indicators in health are Maternal Mortality and Infant Mortality. These indicators represent a way to evaluate various dimensions of the health status of the population and the performance of the health system. Health indicator is understood as the numerical value of any absolute or relative figure that reflects a specific situation and that by comparisons in time and space allows to observe the substantial changes in specific health situations. ${ }^{20,21}$ The health of two of the most vulnerable social groups ${ }^{22}$ such as women and children can be measured through the Global Index of Maternal and Infant Mortality (GIMIM) which is a summary indicator proposed as a construct based on the two highest social impact mortalities, it also reflects the living conditions of the population; from this indicator, a substantive value of mortality is obtained for each federative entity and can be subject to a prioritization exercise.

Its calculation is made from the "Principal Component Analysis" that aims to reduce the dimensions of a problem of multiple variables, applying a succession of linear transformations to the variables so that a subset of them will concentrate most of the variability contained in the original variables. ${ }^{23}$

Assuming we have $\mathrm{n}$ subjects and $\mathrm{p}$ variables, with these data it is possible to form a matrix of $\mathrm{n}$ lines by $\mathrm{p}$ columns in which there are more subjects than variables $(n>p)$.

The GIMIM varies between 0 and 100 . Its value expresses the magnitude of mortality, while closer to 100 this means that mortality is higher, therefore, it is a method of prioritization. Its mathematical formulation is:

$$
G I M I M=0.5(M M I+I M I)
$$

Where GIMIM stands for Global Index of Maternal and Infant Mortality; 0.5 represents the proportional fraction of the hundredth; MMI is the Maternal Mortality Index; IMI is the Infant Mortality Index.

For the construction of each of the two components the following formula was used:

$$
\mathrm{IMI}=\frac{\text { MIi-MImin }}{\text { MImax }- \text { MImin }} \times 100
$$

Where IMI is the Infant Mortality Index; MIi represents the value that you want to prioritize (Tables $1 \& 2$ ),

Table 1 Matrix for the construction of the global index of maternal and infant mortality

\begin{tabular}{lllll}
\hline \multirow{2}{*}{$\begin{array}{l}\text { Mortality } \\
\text { indicator }\end{array}$} & \multicolumn{2}{l}{ Minimum } & \multicolumn{2}{l}{ Maximum } \\
\cline { 2 - 5 } & Value & State & Value & State \\
\hline Infant & 8.6 & Nuevo León & 14.5 & Puebla \\
Maternal & 14.8 & Nuevo León & 65.4 & Campeche \\
\hline
\end{tabular}

MImáx represents the maximum value of the population you want to compare with (Tables $1 \& 2$ ), and

MImín represents the minimum value of the population you want to compare with (Tables $1 \& 2$ ).

In example: To calculate the IMI that is the Infant Mortality Index of the State of Aguascalientes using the formula described:

$$
\mathrm{IMI}=\frac{9.5-8.6}{14.5-8.6} \times 100
$$

Where IMI is the Infant Mortality Index; MIi represents the rate of Infant Mortality in Aguascalientes, which is 9.5 deaths of children under one year of age per 1,000 live births; MImáx represents the Infant Mortality rate in Puebla, which is 14.5 deaths of children under one year of age per 1,000 live births, and MImín represents the Infant Mortality rate of Nuevo León, which is 8.6 deaths of children under one year of age per 1,000 live births.

In this case, the IMI is 15.25 for the state of Aguascalientes ${ }^{24}$ (Table 2 and Figure 1). Considering that the most sensitive indicators of population health are Maternal Mortality and Infant Mortality, achieving the reduction of these two mortalities will be another challenge of the Fourth Transformation.

\section{Nursing coverage}

In Mexico, the nursing profession is ruled by a broad legal framework in which the Official Mexican Standard that regulates its practice (NOM-019-SSA3-2013) stands out. It defines nursing as "Science and humanistic art dedicated to the maintenance and promotion of the well-being of people's health, it has developed a comprehensive vision of the person, family and community and a series of knowledge, principles, foundations, skills and attitudes that have allowed the profession to promote, prevent, educate and investigate about the health care through dependent, independent or interdependent interventions".

Although in recent years the number of human resources within the health system has increased, Mexico still faces a relative deficit of nurses, this staff represents more than $50 \%$ of the total health personnel, until 2015 a total of 223,284 nurses were registered, to look after a population of $118,395,053$ inhabitants with the indicator 
of nurses per 1, 000 inhabitants of 1.89 for the total population; ${ }^{26,27}$ The index of nursing coverage by federal entity per 1,000 inhabitants however, this figure is still well below the OECD average of $8.8 .{ }^{28}$ is seen in Table 2.

Table 2 Social backwardness index, maternal and infant mortality rates, global index of maternal and infant mortality and nursing coverage by federative entity, Mexico 2015

\begin{tabular}{|c|c|c|c|c|c|}
\hline $\begin{array}{l}\text { Federative } \\
\text { entity }\end{array}$ & $\begin{array}{l}\text { Social } \\
\text { backwardness index }\end{array}$ & $\begin{array}{l}\text { Maternal } \\
\text { mortality rate* }\end{array}$ & $\begin{array}{l}\text { Infant mortality } \\
\text { rate** }\end{array}$ & $\begin{array}{l}\text { Global index of maternal } \\
\text { and infant mortality }\end{array}$ & $\begin{array}{l}\text { Nursing care } \\
\text { coverage**** }\end{array}$ \\
\hline Aguascalientes & -1.04 & 25.7 & 9.5 & 18.40 & 1.93 \\
\hline Baja California Sur & -0.40 & 32.1 & 10.8 & 35.74 & 2.49 \\
\hline Baja California & -0.82 & 42.3 & 13.1 & 65.31 & 1.85 \\
\hline Campeche & 0.30 & 65.4 & 10.3 & $64.4 I$ & 2.85 \\
\hline Chiapas & 2.39 & 54.8 & 12.4 & 71.73 & 1.53 \\
\hline Chihuahua & -0.59 & 59.8 & 13.1 & 82.60 & 1.6 \\
\hline Ciudad de México & -1.31 & 41.9 & 10.5 & 42.88 & 3.97 \\
\hline Coahuila & -1.06 & 27 & 8.9 & 14.6 & 2.08 \\
\hline Colima & -0.66 & 22.5 & 10 & 19.47 & 2.26 \\
\hline Durango & -0.03 & 41.2 & 10.7 & 43.88 & 1.95 \\
\hline Guanajuato & -0.06 & 34.9 & II.I & 41.05 & 1.74 \\
\hline Guerrero & 2.45 & 59.4 & 13.1 & 82.21 & 1.86 \\
\hline Hidalgo & 0.45 & 37.5 & 12.6 & 56.33 & 1.83 \\
\hline Jalisco & -0.69 & 22.4 & 10.2 & 21.07 & 1.5 \\
\hline México & -0.48 & 36.1 & 13.8 & 65.12 & 1.24 \\
\hline Michoacán & 0.63 & 36.7 & 11.6 & 47.06 & $\mathrm{I} .4 \mathrm{I}$ \\
\hline Morelos & -0.21 & 44.5 & 10.9 & 48.84 & 1.61 \\
\hline Nayarit & 0.01 & 36.1 & 10.1 & 33.76 & 2.06 \\
\hline Nuevo León & -1.36 & 14.8 & 8.6 & 0.00 & 2.18 \\
\hline Oaxaca & 2.54 & 50.4 & 12.4 & 67.38 & 1.83 \\
\hline Puebla & 0.88 & 31.8 & 14.5 & 66.8 & 1.41 \\
\hline Querétaro & -0.43 & 35 & 11 & 40.3 & 1.34 \\
\hline Quintana Roo & -0.40 & 46.2 & 11.5 & 55.60 & 2.17 \\
\hline San Luis Potosí & 0.61 & 31.8 & 11.7 & 43.07 & 1.76 \\
\hline Sinaloa & -0.46 & 26.7 & 9.2 & 16.84 & 2.04 \\
\hline Sonora & -0.59 & 40.2 & 10.6 & 42.05 & 1.8 \\
\hline Tabasco & -0.15 & 27.4 & 10.6 & 29.40 & 2.26 \\
\hline Tamaulipas & -0.53 & 41.7 & 10.9 & 46.07 & 2.24 \\
\hline Tlaxcala & -0.17 & 23.2 & 13.3 & 48.13 & 1.97 \\
\hline Veracruz & 1.2 & 46.4 & 11.7 & 57.50 & 1.6 \\
\hline Yucatán & 0.29 & 50.8 & 10.4 & 50.83 & 2.88 \\
\hline Zacatecas & -0.33 & 44.2 & 10 & 40.92 & 1.68 \\
\hline
\end{tabular}

*Per 100,000 live registered births

**Per 1000 live births

***Per 1000 inhabitants 


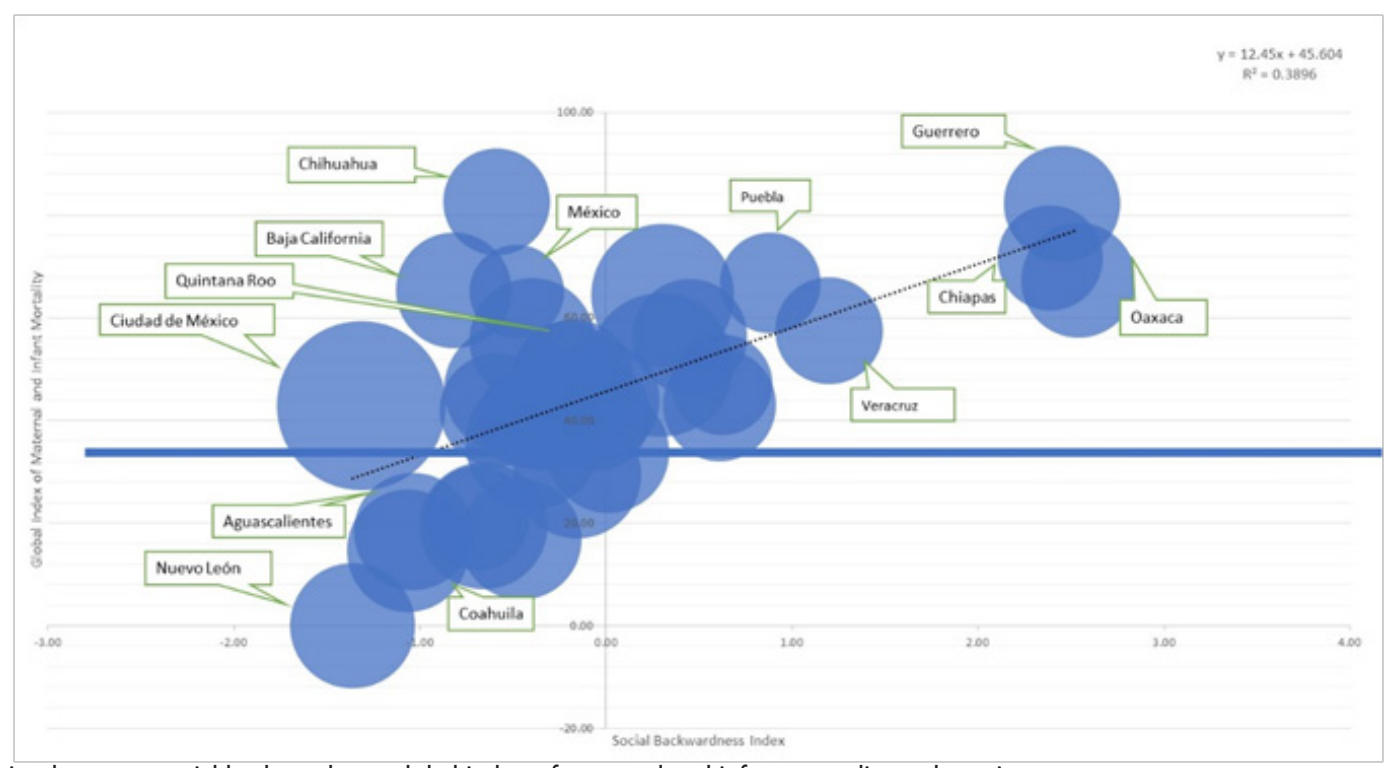

Figure I Dispersion between social backwardness, global index of maternal and infant mortality and nursing coverage.

The main objective of working on the idea of social determinants from the health services is to reduce the inequities in health, that strongly impact health and social conditions of the population.

Through a dispersion exercise where $\mathrm{X}$ corresponded to the Social Backwardness Index, $Y$ to the Global Index of Maternal and Infant Mortality (GIMIM) and Z (size of the dispersion) to the nursing care coverage; the states with the greatest backwardness and the highest GIMIM were Guerrero, Chiapas and Oaxaca as opposed to Nuevo León, Coahuila and Aguascalientes $(\mathrm{p}<.001)$. Likewise, the multiple linear regression was significant for the Social Backwardness Index and GIMIM, Beta value of $-.719, \mathrm{p}<.001$ and $\mathrm{R}^{2}=0.3896$, which would imply that up to $38.9 \%$ of the maternal and infant mortalities would be explained by the Social Backwardness Index; apparently, the nursing coverage does not impact on this model.

\section{Conclusion}

Finally, while a large part of the population sees the idea of the "Fourth Transformation" with optimism, another part doubts the significance that it can achieve; although it is a way of making society realizes that a way to settle the historical backwardness is being looked for. If the Fourth Transformation is fruitful, it will be possible to reduce backwardness index, especially in the states where it is the highest, such as Oaxaca, Guerrero, Chiapas, Veracruz and Puebla, which would lower the rates of Maternal and Infant Mortality; likewise, it should decrease mortality in Chihuahua, Baja California, Estado de Mexico and Quintana Roo. Mexico City deserves a special mention since most of the reference hospitals are concentrated in this city, so it receives patients in critical conditions of others states of the country which apparently has an impact on overmortality.

\section{Acknowledgments}

None.

\section{Conflicts of interest}

The authors declare there is no conflict of interest.

\section{References}

1. Fuentes Y. AMLO presidente: ¿qué es la "Cuarta Transformación" que propone Andrés Manuel López Obrador para México? BBC News Mundo. 2018;

2. Hernández-Navarro L. La cuarta transformación en México. 2018.

3. Clifford chance. The Fourth Mexican Transformation. 2018.

4. López-Obrador AM. Mensaje a la Nación durante la Transmisión del Poder Ejecutivo ante el Congreso de la Unión. 2018.

5. Suprema Corte de Justicia de la Nación. Constitución Política de los Estados Unidos Mexicanos.

6. Poder Ejecutivo Federal. Ley General de Salud México.

7. Commission on Social Determinants of Health. Closing the gap in a generation: health equity through action on the social determinants of health: final report of the commission on social determinants of health. 2008. $256 \mathrm{p}$

8. Silberman Martín, Moreno-Altamirano Laura, Kawas-Bustamante Víctor, et al. Determinantes sociales de la salud en los usuarios de atención sanitaria del Distrito Federal. Rev Fac Med (Méx). 2013;56(4):24-34.

9. Krieger N. A glossary for social epidemiology. Journal of Epidemiology and Community Health. 2001;55(10):693-700.

10. Tarlov A. Social determinants of Health: the sociobiological transition In: Blane D, Brunner E, editors. Health and social organization. UK: Routledge; 2000. p. 71-93.

11. Comisión sobre Determinantes Sociales de la Salud. Subsanar las desigualdades en una generación: alcanzar la equidad sanitaria actuando sobre los determinantes sociales de la salud: Informe final. 2008;56(4):24-34.

12. Sitio Oficial de Andrés Manuel López Obrador. Anuncia presidente Plan de Salud Integral; 2018.

13. Presidencia de la República. Presidente López Obrador presenta Plan Nacional del IMSS 2018-2024.

14. Consejo Nacional de Evaluación de la Política de Desarrollo Social. Índice de Rezago Social 2015. 2015. 10 p. 
15. Consejo Nacional de Evaluación de la Política de Desarrollo Social. Los mapas de Pobreza en México. Anexo técnico metodológico. 2007. 10 p.

16. Centro de estudios en asuntos públicos. Modificaciones a la Medición del Rezago Social en México. 2016. 50 p.

17. Organización Mundial de la Salud. Mortalidad Materna. 2018.

18. Secretaría de Salud. Dirección General de Información en Salud. Boletín de Información Estadística 2014_2015.2015.47 p

19. Instituto Nacional de Estadística e Informática. Mortalidad en México. 2018 .

20. De la Fuente-Ramírez, Tapia-Conyer R, Lezana-Fernández MA. La información en salud. Mexico: McGraw-Hill Interamericana; 2002. p. 171-173.

21. Prah-Ruger J. Health and social justice. Lancet. 2004;364(9439):10751080 .

22. Commission on information and accountability for women's and children's health Keeping promises, measuring results. Geneva: World Health Organization; 2011. 30 p.
23. Galbiati J. Components principals

24. Camposortega-Cruz S. Población, bienestar y territorio en el Estado de Hidalgo, 1960-1990. Universidad Autónoma del Estado de Hidalgo. 1997. p. 43-49.

25. Secretaría de Salud. Norma Oficial Mexicana NOM-019-SSA3-2013, Para la práctica de enfermería en el Sistema Nacional de Salud. 2013. p $1-11$.

26. Secretaría de Salud México. Dirección General de Información en Salud. Sistema Nacional de Información en Salud. 2017.

27. Instituto Nacional de Estadística y Geografía. Anuario estadístico y geográfico por entidad federativa 2013.2013.Consejo Nacional de Población. Proyecciones de la población en México, 2010-2050.

28. Estadísticas de la OCDE sobre la salud 2014. México. 2014. 3 p. 